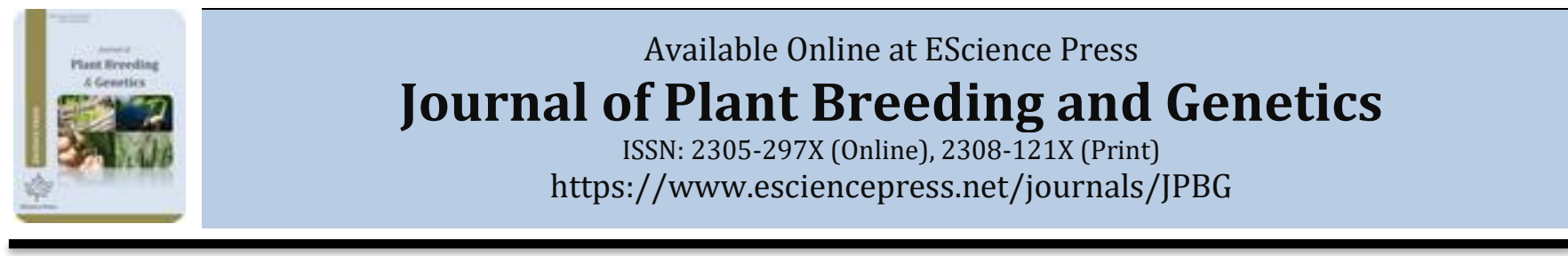

\title{
SCREENING OF BREAD WHEAT GENOTYPES ON PHYSIOLOGICAL AND AGRONOMICAL TRAITS IN HIGH TEMPERATURE AT DIFFERENT PLANTING
}

\author{
aWashu Dev*, aXiaoli Geng*, aDaowu Hu, bShabana Memon, bAamir A. Abro, bSadaf Memon \\ a State Key Laboratory of Cotton Biology Institute of Cotton Research, Chinese Academy of Agricultural Sciences, Anyang, China. \\ b Department of Plant Breeding and Genetics Sindh Agriculture University, Tandojam 70060, Pakistan. \\ * These authors contributed equally: Washu Dev and Xiaoli Geng \\ Corresponding Author: Washu Dev Email: devwashu786@gmail.com
}

\begin{abstract}
A B S T R A C T
The most crucial factors that reduce developments of plants are the Abiotic stresses. Among abiotic stresses, high temperature is the imperative factor that causes a reduction in crop growth and effect yield. Nowadays, the temperature of Pakistan has raised with approximately $<50^{\circ} \mathrm{C}$, affecting the wheat crop from anthesis stage till maturity and hence, limiting the productivity of wheat. This study focuses on examining the effects of high temperature on wheat genotypes when planted with different sowing date viz. $10^{\text {th }}$ November and $20^{\text {th }}$ December of the year 2017-18, using Randomize Complete Bloch Design (RCBD). Product yield from both sowing dates (early and late) were observed with significant difference in all types of genotypes; for days $75 \%$ maturity, 1000 -grains yield, grain yield $\left(\mathrm{kg} / \mathrm{ha}^{-1}\right)$, biological yield $\left(\mathrm{kg} / \mathrm{ha}^{-1}\right)$ and in some physiological characters such as area $\left(\mathrm{cm}^{2}\right)$ of flag leaf, relative percent of water content $(\%)$ and chlorophyll content $\%$ at the probability level $\mathrm{P} \leq 0.01$ and probability level $\mathrm{P} \leq 0.05$. The early and late planting revealed significant different recorded in RWC (\%) and Leaf Area. The late sowing date, the trait RWC (\%) shown non-significant result. The maximum reduction recorded in HYT 10 advance line for grain yield $\mathrm{kg} / \mathrm{ha}^{-1}$, leaf area and RWC and in HYT 09 more reduction of chlorophyll content was observed. Hence, it was due to delayed planting effect and heat stress.
\end{abstract}

Keywords: Wheat, Heat Tolerant, Sowing Time, Physiological traits.

\section{INTRODUCTION}

The second-largest staple food crop in the world after rice is Wheat (Triticum aestivum L.). It accounts for almost $30 \%$ of global cereal production, covered about two hundred twenty million hectares with an average production of 3,2 tons ha-1 $(\mathrm{FAO}, 2015)$. Approximately $95 \%$ of the world's wheat grown is hexaploid $2 \mathrm{n}=6 \mathrm{x}=42$ ). It is produced in huge areas of the world under favourable weather conditions. It provides less source of calories, protein, and carbohydrates in human nutrition (Singh et al., 2016). In Pakistan, it covers a large cultivated area of about $37 \%$ of the total crop (Farooq et al., 2008). It is the leading food crop covering the most extended area under a single plant in Pakistan. It has a major share in the country's GDP of $2.1 \%$ and contribution to agriculture is $10 \%$ (Farooq et al., 2007).
The growing of wheat reduced due to elongated winter season and unprecedented rainfall in April and May, which damaged grain during harvest (GOP, 2014-2015). Wheat crops have been affected by various abiotic stresses such as high-temperature, soil moisture deficits, low light intensity. high-temperature is considered to be the main factor in reducing the wheat yield among the different stresses (Modarresi et al., 2010). Unexpectedly weather change for a few days is not a problem but become challenging to deal with agriculture and weather conditions. Both are interconnected processes and take place on a global scale. Recently, the average global temperature is projected to rise about $2^{\circ} \mathrm{C}$ over the next 50 years, assembly of many kinds of cereal growing regions less suitable, based on predicted temperature (Wrigley et al., 
2006). It is a long-day crop that is physiologically sensitive and requires the collection of units of hightemperature above the threshold or base temperature (before growth) to improve physiologically from sowing to development. It is an abiotic factor restricting the yield impacting decreased wheat and development, leading to low production in numerous countries of the world (Modarresi et al., 2010). It is a vital determinant of physiological and morphological progress affecting harvest growth and yield. From the primary stage of wheat development, heat stress harms wheat crops. Wheat seedlings exposure to heat for a short time lead to decrease root and cause short length, dry weight, chlorophyll content and membrane stability index, that measures the high-temperature cell membrane tolerance (Gupta et al., 2013). The effects of temperature on plants, higher than the optimal temperature, are considered as heat stress (Kumar et al., 2015).

High-temperature is depending on heat intensity, which is a measure of an increase in temperature over the natural warmth, the length of the presentation to hightemperature, rate of temperature rises and plant reaction to high-temperature at various stages of formation. The warmth stretches recognized as a critical point for the end-use of wheat. It is also observed that temperature is strongly related to sedimentation estimates, dissolvable and insoluble proteins and mixotrophic tallness, which is the expansion of the heat, increase these qualities and the other way around while the flour yield, mixing time and mixing resistance of the batter were observed to be altogether diminished because of fast-drying up amid maturing (Tahir et al., 2005). The protein content also found to increase significantly due to exposure to heat stress after anthesis, however, on the other hand, the glutenin/gliadin ratio, which determines a quality of the flour, followed an opposite trend, which reduced its value in response to heat stress (Ashraf, 2014).

Physiologically yield of a crop depends on the photosynthesis and ability of grains to utilize photosynthetic for its growth, and high-temperature has many adverse impacts on both these processes. Photosynthesis is adversely affected, reducing the various physiological traits and intercellular $\mathrm{CO}^{2}$ concentration under high-temperature condition. Physiological and yield parameters determine the heat tolerance in wheat (Balla et al., 2014). Photosynthesis is a critical physiological process in plants that involves various enzymatic reaction, thus making this process very susceptible to heat stress.

Sowing time can be manipulated to prevent the hot and desiccating wind during grain filling period that ultimately determines the yield of the crop. The optimum seed time for wheat crops in India is the first two weeks of November. The seed was a delay until the first two weeks of January, mainly due to late paddy harvest, delays in field operations, climate change. Growth sown in mid-November is the better and maximum height of plant followed by late November sowing, as reported by (Mukherjee et al., 2012; Singh et al., 2008), and also stated the same results. These results exposed to the fact that the increase in temperature that causes the Cultivation to enter the next stage without much development for the next step. The crop sown on 20 November was reported to have produced a significantly higher index of leaf area (4.4) than the crop planted on 20 December (3.9) (Khichar et al., 2007). Also, the delay in sowing reported reducing the LAI (Ram, et al., 2012). The experiment also concluded that on 15 December the LAI was considerably higher in seeding than on 1 January at 50 and 90 DAS. Brushes and leaves, sunburns on leaves, stalks and branches, leaf senescence and abscission caused by the high-temperature stress are the leading cause of lower leaf area index in Late crop sown. The accumulation of dry matter with the timely sown crop $(879,9$ gm-2) was also significantly higher than the late crop $(662,6 \mathrm{gm}-2)$, whereas the height of the plant, the accumulation of dry matter and the tillers per meter line length were considerably good. Hence, the crop sown early was good in comparison to late sown in a various set of parameters (Jat et al., 2013). The crop planted on 10th Nov showed significant height, dry-matter accumulation plant- 1 and number of tillers than the rest of the seed dates had achieved. The collection of dry matter decreased with a Sowing delay from timely (21 November) to very late 7 January (Shivani et al., 2003).

\section{MATERIALS AND METHODS}

High-temperature is critical caused day after day less production. The purpose of this experiment to screening Ten advance wheat genotypes/lines developed through different breeding techniques evaluated for terminal heat stress conducted in RCBD and sown at early planting (20th November) and late planting (10th December 2015), with four replications during Rabi season, 2017 18. Each genotype was sown in four rows $(2.7 \mathrm{~cm}$ row to row distance) 5-meter long row length planted to assess 
the response of wheat genotypes for heat tolerance. In this context, the experimental materials evaluated in two sowing dates, considered as usual and heat stress conditions, respectively. Data on various morphological and physiological characters were recorded to study the outcomes of high-temperature on these yields and yield contributing traits. Temperature data was also recorded at the experimental station during the cropping season to evaluate heat-stress effects during grain filling (terminal heat shocks) and the genotype response to these shocks due to late sowing. Temperatures as minimum and maximum were daily recorded during entire cropping season at the experimental site from SAU, Tandojam.

\section{Relative Water Content \%}

Relative Weight content (RWC) is calculated by collecting samples of flag leaves in polyethylene bags and making it reach at the laboratory as fast as possible in order to reduce the effect of evaporation. First, the fresh weight (FW) of samples is also taken immediately, then $2 \mathrm{~cm}$ size sliced sections are floated for 4 hours on distilled water. The leaf discs are blotted quickly to remove extra water from the surface and weighed to observe turgid weight. Later, these are kept in an oven at $60^{\circ} \mathrm{C}$ for 24 hours to dry and weight again (DW). RWC is calculated using a reported method (Barrs et al., 1968). A mathematical formula:

RWC $(\%)=[(F W-D W) /(T W-D W)] \times 100$

\section{Heat Susceptibility Index (HSI)}

(HSI) Is used for evaluating the effect of high-temperature for the thousand-grain weight (TGW). The formula used for HSI calculation, taken from Paliwal et al. (2012) is given below:

HSI of X= [(1- X-heat stress $/ \mathrm{X}$ control $) / D]$

\section{Meteorological Data}

Minimum and maximum temperatures on a daily basis were recorded during the entire cropping season at the experimental site from SAU, Tandojam.

\section{Statistical Analysis}

Statistical analysis for each genotype sample was done using the collected data from various parameters. The analysis of variance technique applied to determine the significant difference among the means.

The analysis of variance for all the traits carried out separately as reported in (Gomez and Gomez 1984) to generate significance among various bread wheat genotypes planted under non-stress and heat stress conditions with the following statistical formula.

Where:

QUOTE $\sigma^{2} \mathrm{e}=$ Environmental variance, QUOTE $\sigma^{2} \mathrm{~g}=$ Genetic variance and

QUOTE $\sigma^{2} \mathrm{t}=$ Treatment variance

\section{Temperature during the experimental period}

The temperature during the whole period of the wheat season found to be variable and huge differences observed for all the traits under both sowing dates. The meteorological data on daily basis for minimum and maximum temperatures measured during entire cropping season (2017-2018) at experimental site are given in (fig 1.) the high-temperature was noticed during the sowing of an experiment in November, however, the temperatures decreased in December and January. From February to May, the temperature rises about by $5{ }^{\circ} \mathrm{C}$ averagely for each month. At the time of grain filling period during March, the temperature reached at $35{ }^{\circ} \mathrm{C}$ which exceeded up to $40^{\circ} \mathrm{C}$ at 1 st week of April 2018. This situation of temperature is above from the threshold value $\left(25^{\circ} \mathrm{C}\right)$ of cereals crops. Consequently, late planted of wheat crop faced terminal heat stress.

High-temperature of $40^{\circ} \mathrm{C}$ persisted on 27th November and the last week of November. The temperatures from December till March were relatively favorable for wheat crop planted in normal condition while low and HT during anthesis and grain formation stage were not suitable as crop planted in late. (Fig. 1) During the 2rd week of February (15 days after anthesis) moderately HTs were recorded $\left(30{ }^{\circ} \mathrm{C}-37{ }^{\circ} \mathrm{C}\right)$ till 4 th week of February. The temperature increased in March till the (39 ${ }^{0} \mathrm{C}$ ). Disastrous temperature was observed in the end of March and month of April $\left(>40^{\circ} \mathrm{C}\right)$. Consequently, HT range prevailed from $31{ }^{\circ} \mathrm{C}$ to $45^{\circ} \mathrm{C}$ from the month of March till the second week of April. 


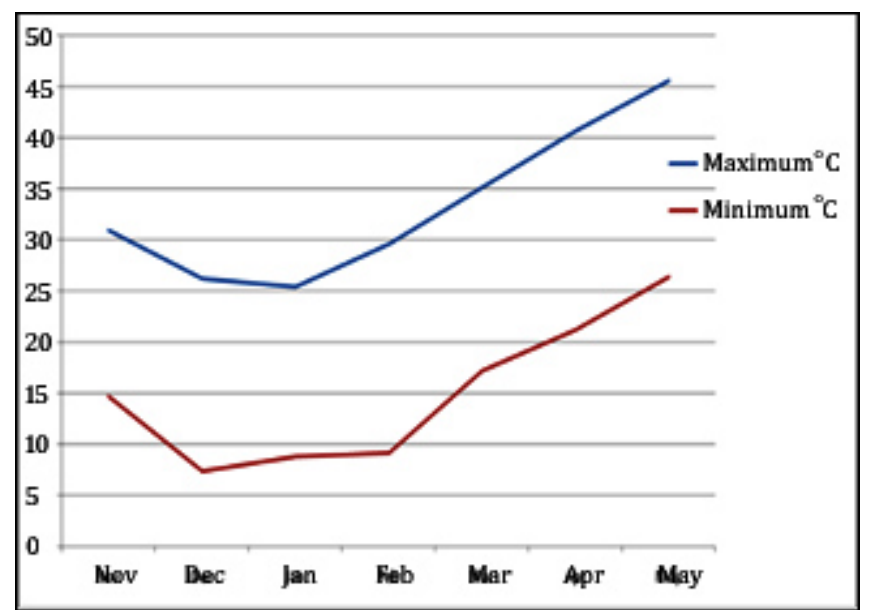

Figure 1. Maximum and minimum temperature of wheat season 2017-2018.

\section{RESULTS}

Analysis of variance show significance of combined mean squares of variance for two different plantings (early and late) which were significant for days to maturity $75 \%$, 1000 -grain weight, grain yield $\left(\mathrm{kg} / \mathrm{ha}^{-1}\right)$, biological yield $\left(\mathrm{kg} \mathrm{ha}^{-1}\right)$, flag leaf area $\left(\mathrm{cm}^{2}\right)$, relative water content\%, chlorophyll content $\%$. The considerable differences

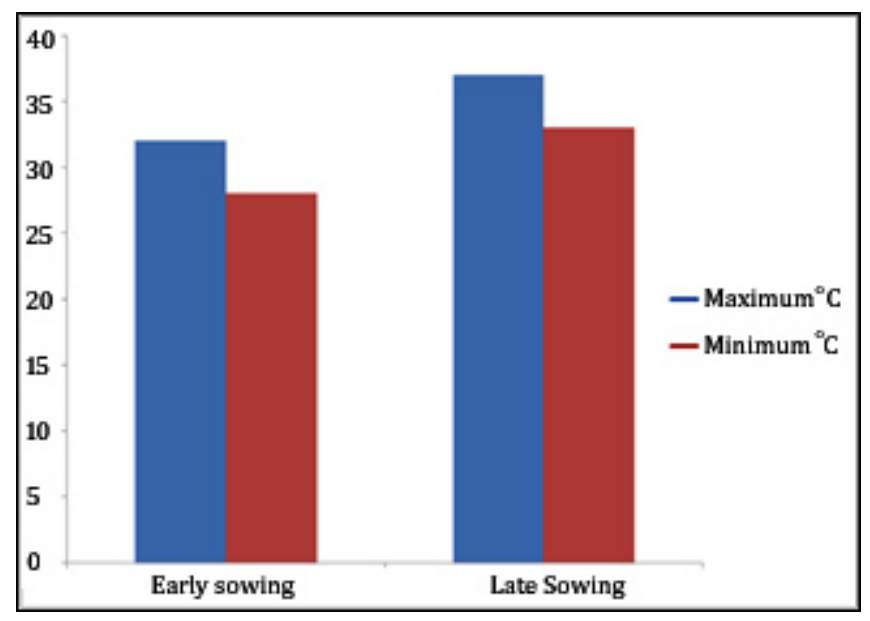

Figure 2. Maximum and minimum temperatures of the wheat crop at 20th February to 20th March, at SAU, Tandojam.

found among the all genotypes yielded and their physiological traits at probability level $\mathrm{P} \leq 0.05$. The mean squares found from analysis of variance for genotype $\mathrm{x}$ treatment interaction were also significant at probability level $\mathrm{P} \leq 0.01$ for all the traits. The significance of genotype $x$ treatment interactions showed that genotypes performed variably over the stress conditions.

Table 1. Mean squares from analysis of variance for various morpho-physiological traits of advance wheat lines grown under normal and late sowing dates.

\begin{tabular}{lccccc}
\hline \multicolumn{1}{c}{ Traits } & $\begin{array}{c}\text { Replication } \\
\text { (D.F.=3) }\end{array}$ & $\begin{array}{c}\text { Genotype (G) } \\
\text { (D.F.=09) }\end{array}$ & $\begin{array}{c}\text { Treatment (T) } \\
\text { (D.F.=1) }\end{array}$ & $\begin{array}{c}\text { G x T } \\
\text { (D. F=09) }\end{array}$ & $\begin{array}{c}\text { Error } \\
\text { (D.F.=57) }\end{array}$ \\
\hline Days to 75 \% maturity & 4.18 & $23.61^{*}$ & $1174.20^{*}$ & $12.87^{*}$ & 1.56 \\
1000-grains weight (g) & 10.40 & $10.46^{*}$ & $476.58^{*}$ & $5.74^{*}$ & 3.61 \\
Grain yield (kg/ha-1) & 46605 & $53162^{*}$ & $1556541^{*}$ & $31394^{*}$ & 13931 \\
Biological yield (kg/ha-1) & 417737 & $388345^{*}$ & $762256^{*}$ & $263803^{*}$ & 102363 \\
Leaf area $\left(\mathrm{cm}^{2}\right.$ ) & 14.51 & $7.18^{*}$ & $195.50^{*}$ & $2.87^{*}$ & 5.80 \\
Relative water content \% & 57.07 & $102.04^{*}$ & $1471.30^{*}$ & $24.67^{*}$ & 19.84 \\
Chlorophyll content \% & 1.10 & $1.03^{*}$ & $22.57^{*}$ & $1.06^{*}$ & 0.42 \\
\hline
\end{tabular}

\section{Days 75\% Maturity.}

Wheat genotypes/lines showed a significant difference in different sowing dates, maximum reduction observed in HYT 07 (8.49\%) under stress condition. The exceptional performance recorded by HYT-01 with a minimum relative decrease of $(2.08 \%)$ with less decline in heat stress condition. In non-stress, days, $75 \%$ maturity observed in HYT 07 and HYT 08 (125.50, 124.90). Whereas, HYT 01 (116.58) significantly showed lesser days as when sown in 20th November, which revealed earliness for maturity Almost all the advance lines revealed to be statistically similar for this trait. However, HYT 08 and HYT 10 matured earlier sown on December $20^{\text {th }}$. This difference was due to a Heat Tolerant (Nahar et al., 2010).

\section{0-Grains weight}

1000-grains weight it also yields contributing traits while terminal heat stress is the primary environmental factor which reduces the size and boldness of grain, the reduction in the grain-filling period. On average, heat stress caused a reduction of $30.63 \%$ in 1000 -grain weight 
under the late sowing date. The highest 1000-grain weight was weighed in genotype HYT-5 (49.06 g) and the lowest in HYT-2 (44.06 g) under early sowing, while in late sowing, the maximum 1000-grain weight observed in genotype HYT-6 (43.74 g) and minimum (40.28g) in HYT-

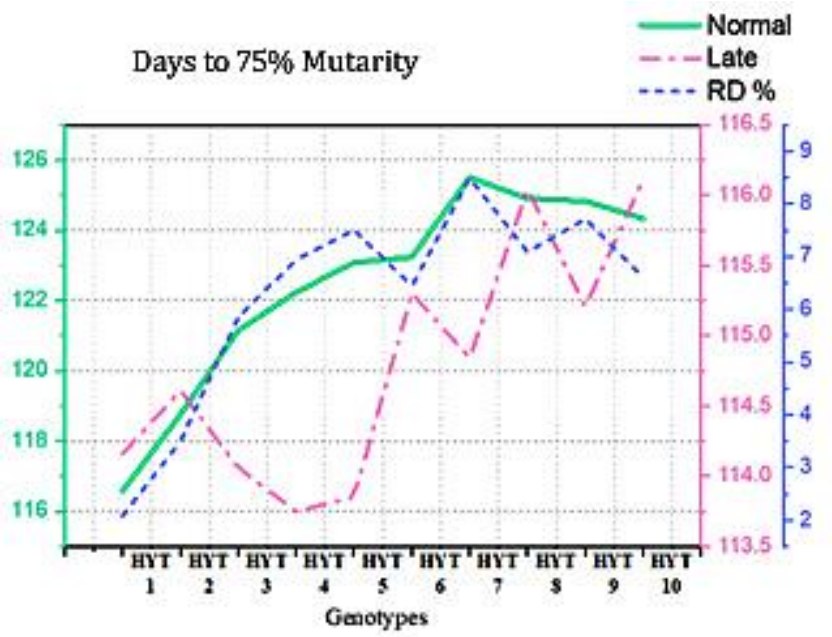

Figure 3. Mean performance of Days to 75\% Maturity of bread wheat genotypes different sowing dates.

\section{Grains yield (kg/ha-1)}

Higher grain yield is the primary goal of all the plant breeders. The mean performance of all the genotypes at early sowing was (2785.0 g). However, at late sowing it was (2506.0 g). On an average, $10.02 \%$ loss in grain yield (kg/ha-1) occurred due to late sowing. The highest performance observed in HYT-6, with minimum reduction (3.42\%) and the highest relative decrease \% shown by HYT-8 (15.23 \%) under late sowing. The maximum grain yield (kg/ha-1) obtained by HYT-8 (2953.5 Ka/ha-1) and the minimum by HYT-9 (2563.0 $\mathrm{kg} / \mathrm{ha}-1$ ) in early sowing, while in late sowing the highest grain yield (kg/ha-1) was also shown by HYT-6 $(2665.0$ $\mathrm{kg} / \mathrm{ha}-1)$ and the lowest by HYT-3 (2387.5 kg/ha-1) Hossain et al. (2015).

\section{Biological Yield (Kg/ha-1)}

The most important reason of low yield and low dry matter production in wheat is Heat Stress [24]. An averagely $13.42 \%$ reduction caused by late sowing. The lowest decrease percentage, however, was recorded by HYT-4 (0.49\%), respectively, under the late sowing. The maximum loss has seen in HYT-7 with decrease percentage of (25.86\%). The higher biological yield exhibited by genotype HYT-7 was (5914.3 kg/ha-1) and lowest by HYT-2 (5336.3 kg/ha-1) in early sowing, while
4. The minimum relative decrease of $0.97 \%$ shown by genotype HYT-1, respectively, under late sowing, yet the highest decrease percentage was exhibited by HYT-4 (14.79\%) under late sowing (Hamam et al., 2015).

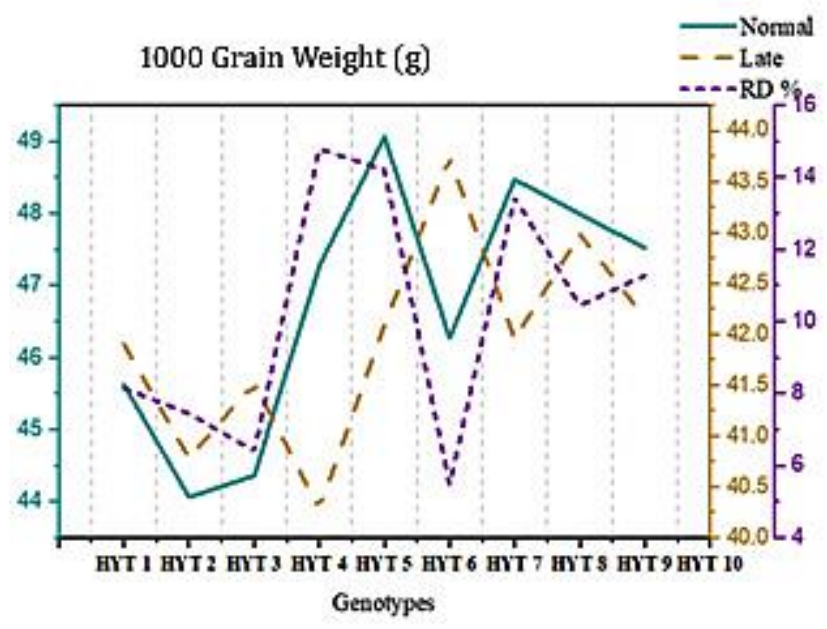

Figure 4. Mean performance of 1000-Grains weight of bread wheat genotypes different sowing dates.

in late sowing, the greater biological yield obtained from HYT-4 (6010.0 kg/ha-1) and the less (4827.5 kg/ha-1) by HYT-10. and Alam et al. (2014) stated that falls in biological yield of among all genotypes planted under heat stress conditions in their experiments. Their results also support our findings.

\section{Flag Leaf Area $\left(\mathrm{Cm}^{2}\right)$}

In this figure the significant difference for flag leaf area of the advance line of wheat genotype at various planting times. the average of Reduction of heat stress caused (16.99\%) decline. The highest loss in flag leaf area observed in HYT-2 (27.22 \%) under heat stress conditions. The lowest decline was noted in HYT-9 $(11.72 \%)$ in heat stress condition. respectively, the maximum flag leaf area found in HYT-2 $(21.60 \mathrm{~cm} 2)$ and minimum in HYT-6 (16.83 cm2) under non-stress conditions. Maximum flag leaf area noted in HYT-1 (16.34 $\mathrm{cm} 2)$ and the lowest also in HYT-6 $(14.10 \mathrm{~cm} 2)$ due to heat stress conditions (Blum et al., 2001) suggested that a small leaf area under heat stress is beneficial because it is dehydrated.

\section{Relative Water Content \% (RWC)}

The experiment observed a highly significant difference in the advance line of wheat genotype. The mean 
performance of all the genotypes grown under early sowing was (63.33\%), while in late planting, it was (54.75\%). Heat stress caused a decline of (13.55 \%) on an average, over the genotypes. The best performance for (RWC) under the heat stress condition was given by genotype HYT-8 with the lowest decrement $\%$ age of $(5.08 \%)$ The maximum reduction (15.28 \%) however was recorded in HYT-10 in terminal heat stress condition.

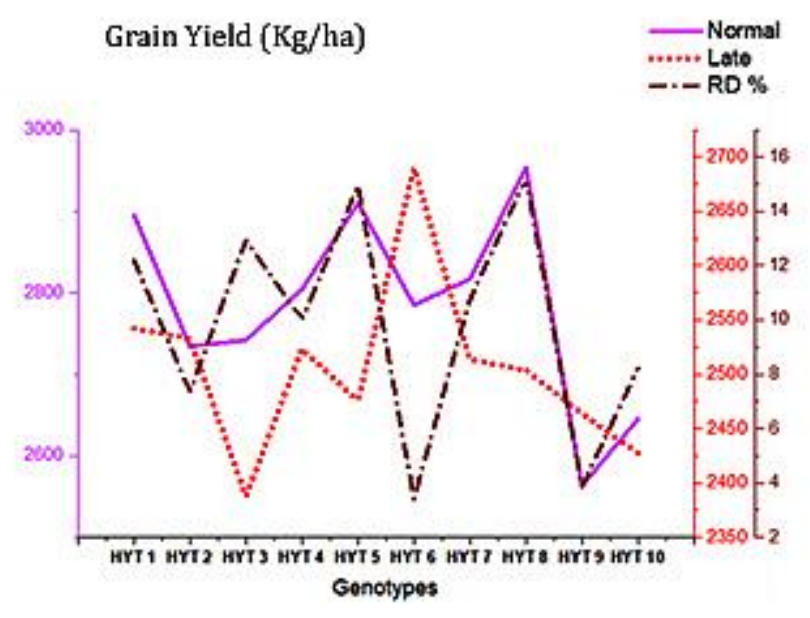

Figure 5. Mean performance of Grain yield (kg/ha-1) of bread wheat genotypes different sowing dates.

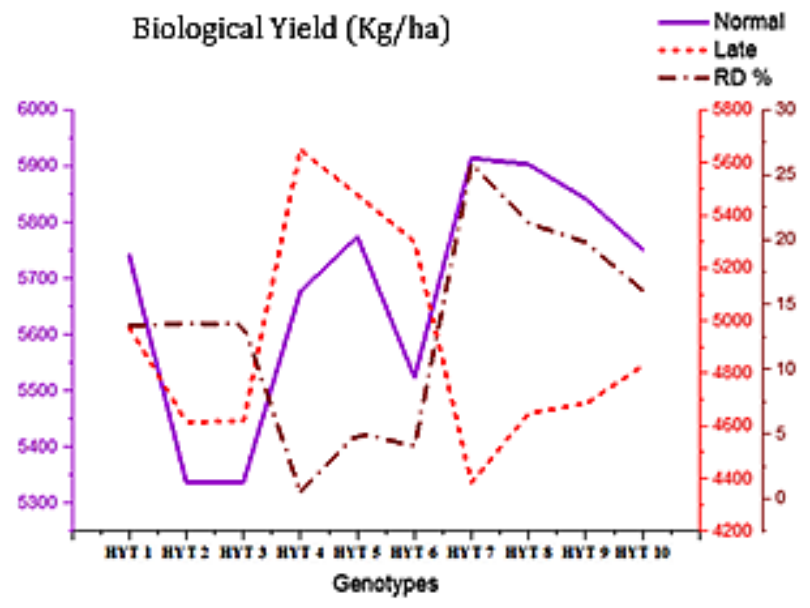

Figure 6. Mean performance of Biological Yield (kg/ha-1) of bread wheat genotypes different sowing dates.

\section{Chlorophyll Content (\%)}

This study recorded chlorophyll content (\%) to the average of heat stress caused $(1.50 \%)$ decline. The highest loss in chlorophyll content was observed in HYT-9 (3.97\%) closely followed by HYT-6 (2.21\%) under heat stress conditions. The lowest decline was noted in HYT-10 0.43
In early sowing, the highest value noted in genotype HYT$1(72.96 \%)$ and the lowest value was expressed by HYT$7(59.44 \%)$, while in late planting, the higher \% age of decline recorded in HYT-1 (61.81\%) and the lowest in HYT-10 (48.74 \%). Proposed that (Sairam and Saxena 2000) suggested that (RWC) a more meaningful indicator of water status than the water potential of wheat under drought conditions.

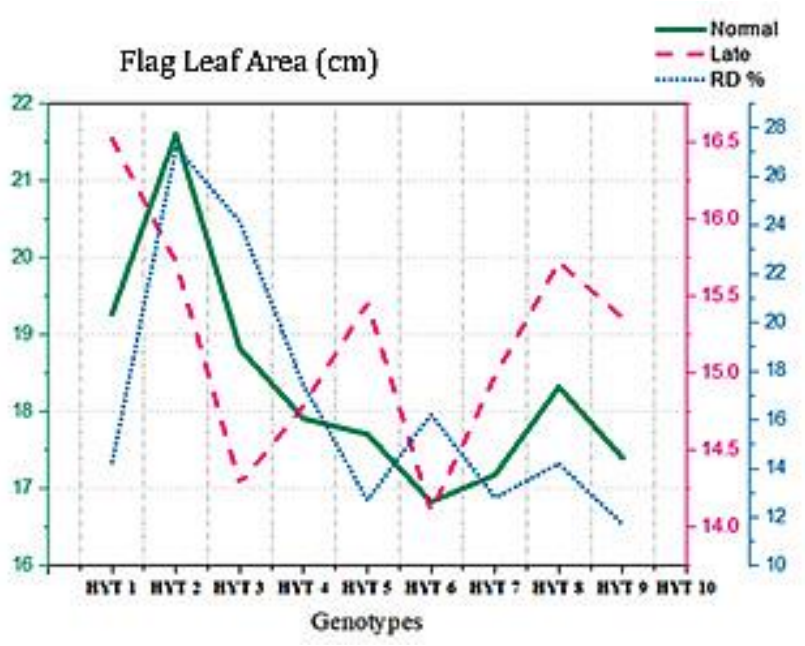

Figure 7. Mean performance of Flag Leaf Area (cm) of bread wheat genotypes different sowing dates.

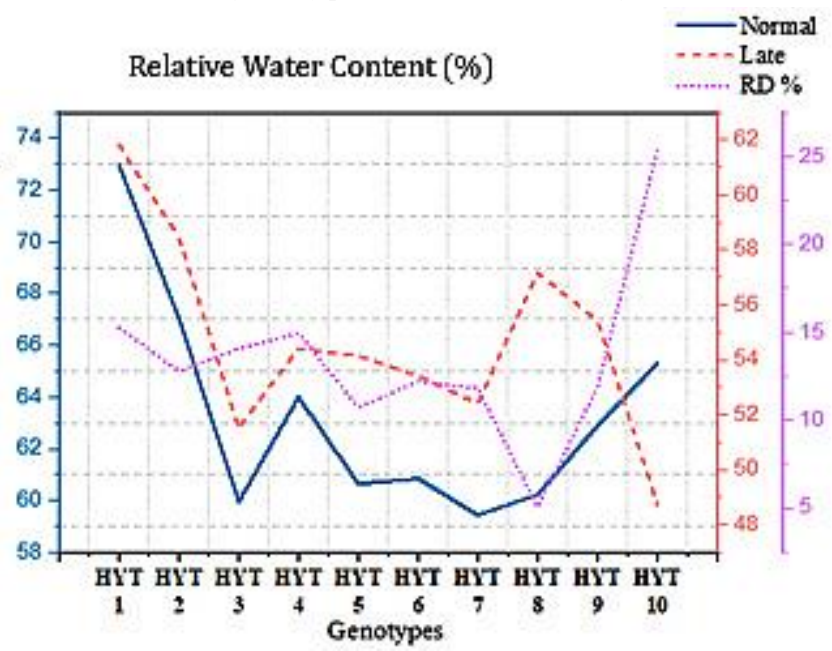

Figure 8. Mean performance of Relative Water Content (\%) of bread wheat genotypes different sowing dates.

$\%$ ) in heat stress condition, respectively. The maximum chlorophyll content found in HYT-9 (71.75 \%) and minimum in HYT-2 (70.17\%) under early sowing. The maximum chlorophyll content was noted in HYT-4 (70.35 $\%)$ and the lowest also in HYT-3 (68.87 \%) due to late planting. Wheat Planting exposure to high-temperature for 
a short time can also lead to a significant reduction in root and shoot length, chlorophyll content, and membrane stability index, which is a measure of cell membrane tolerance at high-temperature (Gupta et al., 2013).

\section{Heat Susceptibility Index (HSI)}

It shows heat susceptibility index (HSI) measures the yield stability based on minimization of yield loss under stress, compared to non-stress condition (Chandra et al., 2014). The advanced lines differentiated into moderate heat tolerant $(\mathrm{HSI}<1)$ and comparatively heat susceptible (HSI>1) groups for each trait. HYT 01 revealed the most heat tolerant genotype having HIS value below the unity for among all of the traits except for, 1000 grain weight and RWC \%. Moreover, HYT 03 advance line was heat tolerant for the traits days to $75 \%$ maturity, grain yield

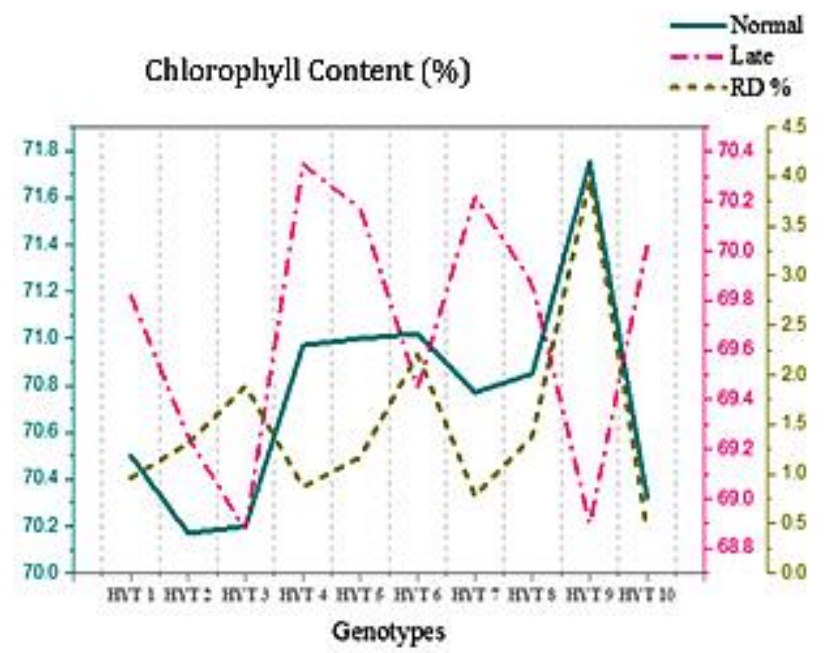

Figure 9. Mean performance of Chlorophyll Content (\%) of bread wheat genotypes different sowing dates.

\section{DISCUSSION}

In abiotic stresses, high temperature is the main factor influencing in reduce wheat development, consequently providing low yield (Modarresi et al., 2010). The current need is to introduce new varieties of wheat that have a high yield, using innovative ideas, incorporating new technologies, to identify the genotypes that could resist environmental changes and potentially produce high grain yield. (Riazuddin et al., 2010). In Pakistan, $80 \%$ of the wheat crop is sown late, only $20 \%$ planted on normal time (Kalra et al., 2008). Hence, to maintain the crop yield various genotypes have to be build up, So that in a specific area the sowing date improving will yield high wheat crop, The effect of high temperature and sowing date has plant-1, biological yield plant -1, flag leaf area ( $\mathrm{cm} 2)$ and chlorophyll content $\%$. Whereas, for the remaining traits 1000 grain weight and RWC\% was relatively found to heat susceptible as the HSI value was above the unity. HYT 05 was also categorized as heat-tolerant genotype as most of the traits were below the unity of the HSI value except for few traits as days to $75 \%$ maturity, 1000 grain weight, grain yield, biological yield plant-1, flag leaf area (cm) and chlorophyll content \%. Accordingly, HYT 06 also revealed to be heat tolerant for all the traits except biological yield and flag leaf area (cm). HYT 10 was observed to heat susceptible genotype for most of the traits except for few traits. Subsequently, genotypes tolerant to heat alongside and other contributing qualities could be used as selection criteria in the breeding program.

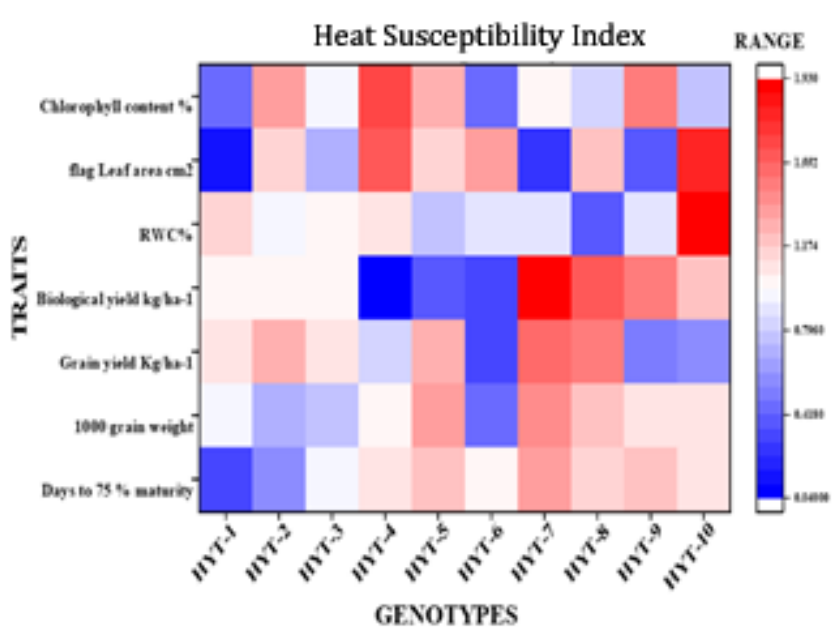

Figure 10. Heat Susceptibility index (HSI) of bread wheat genotypes for various morpho-physiological traits.

great relation with the yield of wheat crop and directly with the development of the wheat crop. The delayed sowing of wheat produces a yield reduction of $50\left(\mathrm{Kg} / \mathrm{ha}^{-}\right.$ ${ }^{1}$ ) d-1 probably after mid-November. (Khan et al., 2010). Early spring has caused the temperature rise, which results in harm to the crop (Mahmood et al., 2010). On the above situation, the present research study was based to assess heat tolerance in newly developed wheat genotypes/ lines in two different sowing dates. The qualities measured at each sowing date were already mentioned at the upper portion. whereas, in cold season heat stress decrease the chlorophyll contents in cereal species, causing physiological damage and most suffered by leaf senescence. (Xu and Huang, 2009). 
The genetic character which is least effected by the environment is the thousand-grain weight. The data was shown a significant difference among the plant dates. The result of 1000-grain weight was shown in (fig.1). Hightemperature affecting the grain maturity which resulted in shrunk kernels. As reported by (Abdullah et al., 2007) traits as 1000 -grain weight is declined successively with delay sowing, (Mondal et al.,2013) and (Hossain et al., 2015) reported that terminal heat stress reduced the seed index. A net effect of lower kernel reduces the grain filling period during high temperatures.

Generally, it is known that heat stress shortens days to $75 \%$ maturity (Hossain et al., 2015).

The reduction in maturity days was also found in the research of (Hossain et al., 2013) with the decrement of $06.26 \%$ under the late sowing dates. This work agrees with (Ishaq et al., 2015) also observed that terminal heat stress significantly affected the physiological maturity and shortened from 10.46 to $12.67 \%$ maturity grown under heat stress conditions. These results were shown in (fig .2) it's also significantly affected planted at normal sowing date as observed in advance line/variety. These results are compatible with (Mumtaz et al., 2015) who reported significant variation among dates and genotypes during days to maturity, anthesis and maturity.

The growth of all other characters provides a better background to increase the grain yield $\left(\mathrm{kg} / \mathrm{ha}^{-1}\right)$. According to (Hays et al., 2007), stress occurring after anthesis often cause detrimental effects on wheat grain yield by hastening maturity, shortening grain filling duration and reducing 1000-grain weight. Heat stress caused a decline of $10.02 \%$ averagely under the late sowing date (fig .4). (El-Ameen et al., 2012) reported that delaying the sowing date resulted in a substantial reduction in grain yield by $63.34 \%$, while the genotypes under favourable conditions performed well for grain yield. Our results agree with (Abd-el-rahman et al. 2014) and Alam et al. (2014) who also have reported that the grain yield up to 40,45 and $49.5 \%$ is reduced due to heat stress, as similarly like the previous result biological yield $\mathrm{kg} / \mathrm{ha}^{-1}$ also highly decreased caused by hightemperature. According to article of (Laghari et al., 2012) and (Hossain et al., 2013) were suggested the heat stress occurred at the anthesis stage of wheat genotypes under the $2^{\text {nd }}$ planting date because of this, a minor effect was noticed on biological yield of $2^{\text {nd }}$ sowing date and their results are in agreement with our conclusions.

As morphological traits were affected at different sowing dates, similarly physiological traits also revealed significant differences. The content of water in crop plant is determined through RWC that tells about the amount of required water in the plant to fully saturate. Terminal heat stress caused a reduction of averagely under the late sowing date in (fig .6) (Ivanov et al., 2001) reported that extreme temperature stresses $\left(45^{\circ} \mathrm{C}\right)$ are closely related to water-deficit due to reduced root water absorption and disruption to stomata control of leaf transpiration temperature, stressed plants suffered for water shortage and reduced relative water content. Our results are in agreement with the findings of the reduced relative water content under the heat stress conditions respectively, Terminal heat stress is a major constraint in the development of flag leaf area. (Singh and Dwivedi 2015) found that heat stress caused by late sowing significantly decreased the flag leaf area The effect of heat stress becomes more clear when we observe the findings of different researchers like heat stress reduced the flag leaf area up to $13.29 \%$ and (Hamam et al., 2015) reported $12.89 \%$ decrease in flag leaf area under late sowing dates with increased heat stress. moreover, chlorophyll content $\%$ also caused by terminal heat stress as like shown in (fig .8). This is same as reported by (Gautam et al., 2016) that the amount of chlorophyll is reduced due to heat stress in the durum wheat genotypes. (Khan et al., 2015) also observed that heat stress significantly reduced chlorophyll contents of wheat genotypes similar to that of (Ahmed and Hassan 2011) and (Kumar et al., 2012).

\section{REFERENCES}

Abdullah, M., A. Rehman, N. Ahmad and I. Rasul. 2007. Planting time effect on grain and quality characteristics of wheat. Pak. J. Agri. Sci., 44(2): 200-202.

Abd-Elrahman, N.M., A.B. Ali, M. Alhadi and Y. Shuang-En. 2014. A field screening of twelve wheat genotypes under late sowing conditions. American-Eurasian J. Agric. \& Env. Sci., 14(10): 978-984.

Alam, M.N., M. Bodruzzaman, M. M. Hossain and M. Sadekuzzaman. 2014. Growth performance of spring wheat under heat stress condition. Int. J. Agron. Agric. Res., 4(6): 91-103.

Ahmad, J. U. and Hassan, M. A. (2011). Evaluation of seedling proline content of wheat genotypes in relation to heat tolerance. Bangladesh Journal of Botany. 40(1):17-22.

Ashraf, M. (2014). Stress-Induced Changes in Wheat 
Grain Composition and Quality. Critical Review. Food Science and Nutrition.54(12): 1576-1583.

Barrs, H.D. 1968. Determination of water deficits in plant tissues. Int. T.T. Kozlowsky Water Deficiency. Pl. Gr. Acad. Pr. New Delhi, 1: 235-268.

Bala S., B. Asthir and N.S. Bains. 2014. Effect of terminal heat stress on yield and yield attributes of wheat. Indian J. Appl.Res., 4(6): 1-2.

Blum, A., N. Klueva, and H.T. Nguyen. 2001: Wheat cellular thermotolerance is related to yield under heat stress. Euphytica. 117: 117-123.

El-Ameen, T. 2012. Stability analysis of selected wheat genotypes under different environment conditions in Upper Egypt. African J. Agric. Res., 34: 48384844.

FA0. 2015. The state of food insecurity in the World.www.fao.org.

Farooq M., S.M.A. Basra, H. Rehman, and B.A. Saleem. 2008. Seed priming enhancement the performance of late sown wheat by improving chilling tolerance. J. Agron. Crop Sci., 194(2): 55-60.

Farooq, A.M., I. Yaqoob and K.N. Sadozai 2007. Varietal adoption effect on wheat crop production in irrigated areas of NWFP. Sarhad J. Agric., 23(3): 807-814.

Gautam, A., Prasand, S. V. S., Ambati, D., Agarwal, D, and Jajoo, A. (2016). Performance of durum wheat genotypes under drought and terminal heat stress conditions in changing climatic conditions. Res \& Review: J Botanical Sciences, 5:4-5.

Giaveno, C. and J. Ferrero. 2003. Introduction of tropical maize genotypes to increase silage production in the central area of Santa Fe, Argentina. Crop Breed. Appl. Biotech., 3: 89-94.

GOP. 2014-15. Economic Survey of Pakistan. 2014-2015. Ministry of Food, Agriculture, and Livestock, Government of Pakistan, Statistics Division (Economic Wing), Islamabad.

Gomez K. A and A. A. Gomez. 1984. Statistical procedure for agricultural research with emphasis on rice. 2nd Ed., IRRI, Los Banos, Philippine.

Gupta N.K., S. Agarwal V.P. Agarwal, N.S. Narathiwat, S. Gupta, and G. Singh. 2013. Effect of short term eat stress on growth, physiology, and antioxidative defense system in wheat seedlings. Acta Physiol. Plant, 35(1):1837-184.

Hamam, K.A., A.G.A. Khaled and M.M. Zakaria. 2015. Genetic stability and diversity in yield components of some wheat genotypes through seasons and heat stress under different locations. J. Pl. Prod. Mansoura Univ., 6 (3): 349 -370.

Hays, D.B., J.H. Do, R.E. Mason, G. Morgan and S.A. Finlayson. 2007. Heat stress induced ethylene production in developing wheat grains induced kernel abortion and increased maturation in susceptible cultivars. Plant Sci., 172: 1113-1123.

Hossain, A., M.A.Z. Sarkera, M. Saifuzzamana, J.A.T.D. Silvab, M.V. Lozovskaya, M.M. Akhter. 2013. Evaluation of growth, yield, relative performance and heat susceptibility of eight wheat (Triticum aestivumL.) genotypes grown under heat stress. Int. J. Pl. Prod., 7(3): 615-636.

Hossain, M.I., M.A. Hakim, M.R.I. Mondal, M. Gathala and N.C.D. Barma. 2015. Phenological variation and its relation with yield in several wheat genotypes under normal and late sowing heat stress conditions in Bangladesh. J. Dynamic Agri. Res., 2(1): 1-11.

Ishaq, M., G. Ahmad, K. Afridi and I.A. Khalil. 2015. Genetic potential of newly developed bread wheat advance lines for important traits under normal and late planting dates. European Acad. Res., 2(10): 1316513176.

Ivanov, S., T. Konstantinova, D. Parvanova, D. Todorova, D. Djilianov and V. Alexieva. 2001. Effect of high temperatures on the growth, free proline content and some antioxidants in tobacco plants. Proc. Bulgarian Acad. Sci., 54 (7): 71-74.

Jat L K, Singh S K, Latare A M, Singh R S and Patel C B. (2013). Effect of date of sowing and fertilizer on growth and yield of wheat in an inceptisol of Varanasi. Indian Journal of Agronomy 58(4): 611614.

Kalra N, D. Chakraborty, A. Sharma, H.K Rai, M. Jolly, S. Chander, P.R Kumar, S. Bhadraray, D. Barman, R.B Mittal, M. Lal and M. Sehgal. 2008. Effect of increasing temperature on yield of some winter crops in northwest India. Current Sci., 94(1): 82-88.

Khan, M.B., M. Ghurchani, M. Hussain, and K. Mahmood. 2010. Wheat seed invigoration by pre-sowing chilling treatments. Pakistan Journal of Botany 42:1561-1566.

Khan, S. U., Din, J. U., Qayyum, A., Jan, N. E. And Jenks, M. A. (2015). Heat tolerance indicators in Pakistani wheat (TriticumaestivumL.) genotypes. Acta Bot. Croat.,74(1):109-21. 
Khichar ML, Niwas R. (2007). Thermal effect on growth and yield of wheat under different sowing environments and planting systems. Indian J Agric Res. 41: 92-96.

Kumar, A., R. S. Sengar, R. Singh, A. Rani, G. Shukla, and V. Girdharwal. 2015. Screening of heat tolerance wheat germplasm under late seeded condition. J. Env. Appl. Bioresearch, 3(4): 206-210.

Laghari, K.A., M.A. Sial and M.A. Arain. 2012. Effect of high temperature stress on grain yield and yield components of wheat (Triticum aestivum L.) Sci. Tech. Dev., 31(2): 83-90.

Mahmood, S., A. Wahid, F. Javed, and S.M.A. Basra. 2010. Heat stress effects on forage quality characteristics of maize (Zea mays) cultivars. International Journal of Agriculture and Biology 12:701-706.

Modarresi, M., V. Mohammadi, A. Zali, and M. Mardi. 2010. The response of wheat yield and yield-related traits of high temperature. Cereal Research Communications, 38(1) 23-31.

Mondal, S., R.P. Singh, J. Crossa, J.H. Espino and I. Sharma. 2013. Earliness in wheat: A key to adaptation under terminal and continual high temperature stress in South Asia. Field Crops Res., 151: 19-26.

Mukherjee D. (2012). Effect of different sowing dates on growth and yield of wheat cultivars under the midhill situation of West Bengal. Indian Journal of Agronomy.57(2):152-156.

Nahar K., K. U. Ahamed and M. Fujita. 2010. Phenological variation and its relation with yield in several wheat (Triticum aestivum L.) cultivars under normal and late sowing mediated heat stress condition. Not Sci. Bio., 2 (3): 51-56.

Paliwal, R., Roder, M.S., Kumar, U., Srivastava, J.P. and Joshi, J.P. (2012). QTL mapping of terminal heat tolerance in hexaploid wheat (Triticum aestivum L.). Theoretical and Applied Genetics, 125, 561575.

Ram A, Pannu R K, and Prasad D. (2012a). Effect of management practices on growth, yield, and quality of late sown wheat. Indian Journal of Agronomy. 57(1): 92-95.

R.K. Sairam R.K. and D.C. Saxena, "Oxidative Stress and Antioxidants in Wheat Genotypes: Possible Mechanism of Water Stress Tolerance." Journal of Agronomy and Crop Science, 184: 55-61, 2000.

Riaz-ud-din, G.M. Subhani, N. Ahmed, M. Hussain and A. Rehman. 2010. Effect of temperature on development and grain formation in spring wheat. Pak. J. Bot., 42(2): 899-906.

Shivani, Verma U N and Kumar S. (2003). Growth analysis of wheat (Triticum aestivum) cultivars under different seeding dates and irrigation levels in Jharkhand. Indian Journal of Agronomy.48: 283286.

Singh, P. and. Dwivedi. 2015. Morpho-physiological responses of wheat (Triticum aestivum L.) genotypes under late sown condition. Int. J. Pl. Res., 28(1): 16-25.

Singh P, Abraham T, and Singh S S. (2008). The response of wheat to zero till sowing under rice-wheat cropping system. Proceedings International Workshop on Herbicide resistance management and Zero tillage in rice-wheat cropping system: 105-106.

Singh, R., P.Khajuria, and A.K. Singh. 2016. Effect of heat stress on grain weight in bread weight. Ind. J. Appl. Res., 6(1): 323-327.

Tahir I S A, and Nakata N. (2005). The remobilisation of nitrogen and carbohydrate from stems of bread wheat in response to heat stress during grain filling. J. Agron. Crop Sci. 191: 106-115.

Wrigley, C. 2006. Global warming and wheat quality. Cereal Foods World, 51: 34-36.

$\mathrm{Xu}, \mathrm{Y}$., and B. Huang. 2009. Effects of foliar-applied ethylene inhibitor and synthetic cytokinin on creeping bentgrass to enhance heat tolerance. Crop Science 49:1876-1884.

Mondal, S., R.P. Singh, J. Crossa, J.H. Espino and I. Sharma. 2013. Earliness in wheat: A key to adaptation under terminal and continual high temperature stress in South Asia. Field Crops Res., 151: 19-26.

Hossain, A., M.A.Z. Sarkera, M. Saifuzzamana, J.A.T.D. Silvab, M.V. Lozovskaya, M.M. Akhter. 2013. Evaluation of growth, yield, relative performance and heat susceptibility of eight wheat (Triticum aestivumL.) genotypes grown under heat stress. Int. J. Pl. Prod., 7(3): 615-636.

Hays, D.B., J.H. Do, R.E. Mason, G. Morgan and S.A. Finlayson. 2007. Heat stress induced ethylene production in developing wheat grains induced kernel abortion and increased maturation in susceptible cultivars. Plant Sci., 172: 1113-1123.

El-Ameen, T. 2012. Stability analysis of selected wheat genotypes under different environment conditions in Upper Egypt. African J. Agric. Res., 34: 4838- 
4844.

Abd-Elrahman, N.M., A.B. Ali, M. Alhadi and Y. Shuang-En. 2014. A field screening of twelve wheat genotypes under late sowing conditions. American-Eurasian J. Agric. \& Env. Sci., 14(10): 978-984.

Alam, M.N., M. Bodruzzaman, M. M. Hossain and M. Sadekuzzaman. 2014. Growth performance of spring wheat under heat stress condition. Int. J. Agron. Agric. Res., 4(6): 91-103.

Laghari, K.A., M.A. Sial and M.A. Arain. 2012. Effect of high temperature stress on grain yield and yield components of wheat (Triticum aestivum L.) Sci. Tech. Dev., 31(2): 83-90.

Ivanov, S., T. Konstantinova, D. Parvanova, D. Todorova, D. Djilianov and V. Alexieva. 2001. Effect of high temperatures on the growth, free proline content and some antioxidants in tobacco plants. Proc. Bulgarian Acad. Sci., 54(7): 71-74.

Singh, P. and. Dwivedi. 2015. Morpho-physiological responses of wheat (Triticum aestivum L.) genotypes under late sown condition. Int. J. Pl. Res.,
28(1): 16-25.

Gautam, A., Prasand, S. V. S., Ambati, D., Agarwal, D, and Jajoo, A. (2016). Performance of durum wheat genotypes under drought and terminal heat stress conditions in changing climatic conditions. Res \& Review: J Botanical Sciences, 5:4-5.

Khan, S. U., Din, J. U., Qayyum, A., Jan, N. E. And Jenks, M. A. (2015). Heat tolerance indicators in Pakistani wheat (TriticumaestivumL.) genotypes. Acta Bot. Croat.,74(1):109-21.

Ahmad, J. U. and Hassan, M. A. (2011). Evaluation of seedling proline content of wheat genotypes in relation to heat tolerance. Bangladesh Journal of Botany. 40(1):17-22.

Kumar, R. R., Goswami, S., Sharma, S. K., Singh, K., Gadpayle, K. A. and Kumar, N. (2012). Protection against heat stress in wheat involves change in cell membrane stability, antioxidant enzyme, osmolyte, H2O2 and transcript of heat shock protein. International Journal of Plant Physiology.

Publisher's note: EScience Press remains neutral with regard to jurisdictional claims in published maps and institutional affiliations.

Open Access This article is licensed under a Creative Commons Attribution 4.0 International License, which permits use, sharing, adaptation, distribution and reproduction in any medium or format, as long as you give appropriate credit to the original author(s) and the source, provide a link to the Creative Commons license and indicate if changes were made. The images or other third-party material in this article are included in the article's Creative Commons license, unless indicated otherwise in a credit line to the material. If material is not included in the article's Creative Commons license and your intended use is not permitted by statutory regulation or exceeds the permitted use, you will need to obtain permission directly from the copyright holder. To view a copy of this license, visit http://creativecommons.org/licenses/by/4.0/.

(C) The Author(s) 2019. 